\title{
HUBUNGAN BONITA DENGAN KELAS KESESUAIAN LAHAN (KKL) HUTAN TANAMAN JATI
}

\author{
(THE CORRELATION BETWEEN BONITA AND LAND SUITABILITY CLASS \\ OF TEAK PLANTATION FOREST)
}

\author{
Heru Dwi R, Beny H, Pamungkas B.P \\ Balai Penelitian Dan Pengembangan Teknologi Pengelolaan DAS-Solo \\ Jl. Jend. A. Yani-Pabelan, Kartasura PO. BOX. 295 Surakarta 57102 \\ Telp./Fax : (0271) 716709 dan 716959 \\ *E-mail : rherudwi_61@yahoo.com ${ }^{1}$ \\ Telp/WA: 085642430002, 081393840002
}

Diterima: 16 Februari 2020, Direvisi: 23 April 2020, Disetujui: 17 Meri 2020

\begin{abstract}
ABSTRAK
Pendekatan bonita untuk menunjukan kualitas suatu lahan dapat cepat diketahui pada hutan tanaman yang telah dikelola secara baik. Kesesuaian lahan adalah tingkat kecocokan sebidang lahan untuk penggunaan tertentu, kesesuaian lahan tersebut dapat dinilai untuk kondisi saat ini (kesesuaian lahan aktual) atau setelah diadakan perbaikan (kesesuaian lahan potensial). Penelitian dilakukan di Kabupaten Blora, di Kawasan Hutan Dengan Tujuan Khusus (KHDTK) CemoroModang DS yang terletak pada wilayah kerja BKPH Pasarsore dan BKPH Cabak, KPH Cepu. Penelitian yang dilakukan bersifat survey lapangan melalui inventarisasi terhadap lahan tegakan hutan tanaman jati. Titik amatan yang dipakai untuk pengambilan sampel ditentukan berdasarkan klas umur (KU) hutan dan bonita, yang masing-masing diulang sebanyak 3 (tiga) ulangan. Parameter yang diambil meliputi aspek sumber daya lahan dan aspek tegakan. Hasil ISDL dari masing-masing titik amatan diklasifikasikan berdasarkan atas sifat-sifat potensi dan penghambat. Analisa data ISDL ini akan menghasilkan klas KKL (Klasifikasi Kesesuaian Lahan) tiap titik amatan yang dapat dipergunakan lebih lanjut untuk evaluasi lahan. Untuk selanjutnya KKL akan diklasifikasikan ke dalam 3 kelas yaitu: S1 (sangat sesuai), S2 (sesuai), S3 (sesuai marjinal). Untuk menyetarakan dengan sistem klasifikasi lahan, maka bonita juga di kelaskan : bonita 4-5 adalah sangat baik untuk jati, bonita 3.5 adalah baik untuk jati, bonita 3 menjadi cukup baik untuk jati. Hasil pesetaraan secara umum kelas kualitas lahan versi bonita dengan kualitas lahan versi KKL bahwa dari total 77 petak/plot pengamatan, kriteria/kelas S1 (sangat sesuai) menempati 64\%, S2(sesuai) menempati 25\% dan S3 (sesuai marjinal) menempati 11\%. Dalam masing-masing bonita, pada bonita 3 : S1 menempati 50\%, S2 menempati 44\% dan S3 menempati 6\%; pada bonita 3,5: S1 menempati 65\%, S2 menempati 15\% dan S3 menempati 20\%; pada bonita 4 : S1 menempati 64\%, S2 menempati 24\% dan S3 menempati 12\%; pada bonita 4,5-5: S1 menempati 88\%, S2 menempati $12 \%$ dan S3 menempati $0 \%$.
\end{abstract}

Kata kunci: $\quad$ Inventarisasi Sumber Daya Lahan (ISDL), Kelas Kesesuaian Lahan (KKL), hutan jati, kualita lahan, bonita

\section{ABSTRACT}

The fast way knowing the site quality by bonita approach, is only for well managed forest. Land suitability is fixed level of land width for particular utilization, this land suitability could be valuated at present condition or after improving action. This research conducted on Forest within 
work area of BKPH Pasarsore and Cabak, KPH Cepu. The observation site used as sample plot based on aged class and bonita, each them was three times replicated. Parameters observed consist of land resource aspect and stand aspect. The data analyze of ISDL's outcome was Land Suitability Class in each observation plot, then it could be used as land/site evaluation, then classified into three classes, such as: S1 (very suitable), S2 (suitable) and S3 (marginal suitable). To make the equality between land classification and bonita, thus the bonita also classified into three class, such as: bonita 3 as good enough for teak growth, bonita 3.5 as good for teak growth and bonita 4-5 as very good for teak growth. The equality result in generally, between bonita version and land suitability class version, from totally 77 observation plots, criteria/class 1 1 (very suitable) occupy 64\%, S2 (suitable) 25\% dan S3 (marginal suitable) 11\%. From each bonita, on bonita 3 : S1 occupy 50\%, S2 44\% dan S3 6\%; on bonita 3,5 : S1 occupy 65\%, S2 15\% dan S3 20\%; on bonita 4 : S1 occupy 64\%, S2 24\% dan S3 12\%; on bonita 4,5-5 : S1 occupy 88\%, S2 12\% dan S3 0\%.

Key words : Land Resource Inventory (ISDL), Land Suitability Class (KKL), teak forest, land quality, bonita

\section{PENDAHULUAN}

Penggunaan lahan untuk usaha budidaya harus disertai dengan pengetahuan tentang karakteristik sumber daya lahan yang terkait: 1) potensi dari sumber daya lahan, yaitu sifat kemampuan dan kekuatan yang dimiliki lahan untuk dapat dikembangkan; dan 2) kerentanan dari sumber daya lahan, yaitu sifat mudah tidaknya lahan terkena degradasi (Paimin et al, 2006). Sifat kerentanan dan potensi ini digunakan sebagai dasar pengelolaan lahan agar berkesinambungan dalam menghasilkan suatu produk seperti bahan pangan, hasil kayu maupun hasil terbarukan lainnya.

Site/lahan adalah fenomena penting dalam hutan alam maupun hutan tanaman, yang direfleksikan oleh pertumbuhan dan perkembangan tegakan hutan. Aspek tanah dan iklim adalah dua faktor utama yang mempengaruhi karakter lahan dalam tanaman. Dalam kajian kehutanan, kualitas lahan dievaluasi dengan bantuan indek yang berbeda. Tidak ada indek tunggal berdasarkan parameterparameter lingkungan secara langsung. (Sajjauzzaman, et al. 2005). Program yang logis dan efektif dalam pengelolaan hutan yang intensif dengan tujuan meningkatkan pertumbuhan tidak dapat diimplementasi- kan tanpa ilmu yang memadai tentang hubungan timbal balik antara kondisi lahan dan produktivitas hutan (Sakurai et al, 2002).

Pertumbuhan pohon secara individu atau dalam tegakan sangat ditentukan oleh kualitas tempat tumbuh (Simon, 2007). Masing-masing jenis tanaman menghendaki tempat tumbuh tersendiri karena tiap jenis tanaman mempunyai karakter tersendiri sehingga kualitas tempat tumbuh untuk setiap jenis tanamannya berbeda satu dengan yang lainnya (Parthama et al, 1999).

Pengukuran kualitas tempat tumbuh sebagai langkah awal dan berperan penting dalam perencanaan pengelolaan hutan (Parthama at al, 1999). Simon (2007) menekankan pentingnya pengukuran kualitas tempat tumbuh dalam pengelolaan hutan tanaman dengan maksud: 1) untuk mengidentifikasi produktifitas tegakan dan 2) untuk menyajikan gambaran tentang rencana maupun pelaksanaan kegiatan teknik kehutanan.

Untuk melakukan pengukuran dan penentuan kualitas tempat tumbuh, Simon (2007) menyatakan ada 2 cara yaitu secara langsung dan tidak langsung. Pengukuran secara langsung dengan melakukan analisa 
terhadap faktor-faktor yang mempengaruhi produktifitas hutan seperti: kandungan hara tanah, tekstur dan struktur tanah, kelembaban, temperatur, topografi dan sebagainya. Sedangkan pengukuran kualitas tempat tumbuh secara tidak langsung adalah dengan menggunakan bonita. Bonita merupakan peng-klas-an kesuburan tanah pada suatu lahan hutan tanaman yang disusun dalam suatu kurva dengan parameter peninggi dan umur. Bonita ditetapkan dan berlaku hanya untuk suatu jenis tertentu saja. Bonita suatu jenis tegakan hutan tanaman mempunyai bonita tersendiri yang tidak dapat digunakan sebagai bonita untuk jenis lainnya.

Pendekatan bonita untuk menunjukan kualitas suatu lahan dapat cepat diketahui pada hutan tanaman yang telah dikelola secara baik. Bila lahan tersebut belum dikelola atau baru saja dilakukan penanaman maka akan menjadi pembatas untuk mengetahui kelas kualitas lahannya berdasarkan bonita. Selanjutnya, tanpa/belum diketahuinya bonita suatu petak/lahan hutan maka akan menjadi penghambat dalam proses perencanaan dan pengelolaan tegakan hutan tanaman karena hampir semua strategi dan kebijakan pengelolaan didasarkan pada bonita (Parthama et al, 1999).

Evaluasi lahan adalah suatu proses penilaian sumber daya lahan untuk tujuan tertentu dengan menggunakan suatu pendekatan atau cara yang sudah teruji. Hasil evaluasi lahan akan memberikan informasi dan/atau arahan penggunaan lahan sesuai dengan keperluan (Ritung et $a l, 2007)$. Kesesuaian lahan adalah tingkat kecocokan sebidang lahan untuk penggunaan tertentu. Kesesuaian lahan tersebut dapat dinilai untuk kondisi saat ini (kesesuaian lahan aktual) atau setelah diadakan perbaikan (kesesuaian lahan potensial). Evaluasi lahan merupakan suatu proses analisis untuk mengetahui potensi lahan untuk penggunaan tertentu yang berguna untuk membantu perencanaan penggunaan dan pengelolaan lahan.

Berdasar apa yang telah diuraikan di atas memunculkan pertanyaan penelitian, apakah evaluasi lahan berdasar KKL mempunyai korelasi dengan evaluasi lahan berdasar bonita? Sehingga penelitian ini bertujuan untuk memperoleh informasi mengenai evaluasi lahan berdasarkan inventarisasi sumber daya lahan dalam mengklasifikasikan KKL tegakan hutan tanaman jati di dalam suatu kawasan hutan.

\section{METODE PENELITIAN}

\section{A. Rancangan Penelitian}

Penelitian yang akan dilakukan bersifat survey lapangan dengan cara inventarisasi terhadap lahan tegakan hutan tanaman jati dalam kawasan hutan negara. Pemilihan lokasi dipertimbangkan dalam suatu wilayah tangkapan air dengan tingkatan Sub-Sub DAS. Titik amatan yang akan dipakai untuk pengambilan sampel ditentukan berdasarkan klas umur (KU) hutan dan bonita, yang masingmasing diulang sebanyak 3 (tiga) ulangan. Penentuan titik lokasi menggunakan data sekunder dari RPKH Bagian Hutan yang tersedia di KPH Perum Perhutani. Parameter yang diambil pada masingmasing titik lokasi meliputi aspek sumber daya lahan dan aspek vegetasi.

Analisa hasil aspek sumber daya lahan akan menghasilkan evaluasi lahan, sedangkan hasil analisa vegetasi akan menghasilkan evaluasi vegetasi.

\section{B. Bahan dan Peralatan}

1. Bahan :

- Bahan peta : peta RBI, peta Petak kawasan hutan, peta Administrasi, peta Geologi.

- Data potensi kondisi tegakan hutan jati dalam RPKH Bagian Hutan 
selama tiga jangka (30 tahun terakhir).

- Bahan analisa tanah : pH meter, $\mathrm{H} 2 \mathrm{O} 210 \%, \mathrm{HCl} 30 \%$.

- Bahan ATK dan komputer: blangko Talysheet, bolpaint, kertas, tinta, kertas plotter, USB, hard disk eksternal

2. Alat:

- Munsell Soil Color Chart, GPS, Pisau Lapang

- Cat, Thiner, Kuas, Meteran, Haga, Kompas, Sekop, Cangkul

\section{Lokasi Dan Waktu Penelitian}

Penelitian ini dilakukan di Kabupaten Blora, Propinsi Jawa Tengah, tepatnya di KHDTK Cemoro Modang DS yang terletak pada wilayah kerja BKPH Pasarsore dan BKPH Cabak, KPH Cepu, Perum Perhutani Unit I pada tahun 2011

\section{Analisa Data}

Hasil data ISDL dari masingmasing titik amatan diolah secara sistematik dan diklasifikasikan berdasarkan atas sifat-sifat potensi dan penghambat. Analisa data ISDL ini akan menghasilkan klas KKL (Klasifikasi Kesesuaian Lahan) tiap titik amatan yang dapat dipergunakan lebih lanjut untuk evaluasi kondisi lahan (Fletcher, 1990). Untuk selanjutnya KKL akan diklasifikasikan ke dalam 3 kelas yaitu: S1 (sangat sesuai), S2 (sesuai), S3 (sesuai marjinal). Masing-masing kelas bercirikan sebagai berikut ;

\section{Sangat Sesuai (S1)}

Lahan yang sangat sesuai untuk tanaman jati yaitu memiliki ciri-ciri biofisik sebagai berikut yaitu drainase tanah agak cepat, bahaya banjir tidak ada (F0), pH tanah 5,5 sampai 7,0, kedalaman sulfidik > $175 \mathrm{~cm}$, salinitas $<4$ mmhos/cm, tekstur tanah L (Loam), SCl (Sandy Clay Loam), SiL (Silty Loam), Si
(Silty), Cl (Clay Loam), SC (Sandy Clay), SiCL (Silty Clay Loam), SiC (Silty Clay). Kemiringan lereng $<8 \%$, batuan permukaaan $<10 \%$ dan batuan singakapan $<10 \%$, dan kedalaman efektif $>150 \mathrm{~cm}$, bulan kering $<5$ bulan, curah hujan 1500 - $2000 \mathrm{~mm}$, rata-rata suhu tahunan 26-30 ${ }^{\circ} \mathrm{C}$, erosi sangat ringan (SR).

\section{Sesuai (S2)}

Lahan yang masuk kelas sesuai untuk tanaman jati yaitu memiliki ciri-ciri biofisik sebagai berikut yaitu drainase tanah sedang - cepat, bahaya banjir jarang (F1), pH tanah 5,0 - 5,4 dan 7,1 - 7,5, kedalaman sulfidik $125-175 \mathrm{~cm}$, salinitas 4- 8 mmhos/cm, tekstur tanah SL, struktur Coarse. Kemiringan lereng $8-15 \%$, batuan permukaaan $10-15 \%$ dan batuan singakapan 10-15\%, dan kedalaman efektif $100-150 \mathrm{~cm}$, bulan kering < 5 bulan, curah hujan $2000-2250 \mathrm{~mm}$ dan 1250-1500 mm, rata-rata suhu tahunan 31$25^{\circ} \mathrm{C}$ dan $21-25^{\circ} \mathrm{C}$, erosi ringan (R).

\section{Sesuai Marjinal (S3)}

Lahan yang sangat sesuai marjinal untuk tanaman jati yaitu memiliki ciri-ciri biofisik sebagai berikut yaitu drainase tanah agak terhambat, sangat cepat, bahaya banjir sering (F2), $\mathrm{pH}$ tanah 4,54,9 dan 7,6-8,0, kedalaman sulfidik 100$125 \mathrm{~cm}$, salinitas tidak ada, tekstur tanah LS, liat masif,. Kemiringan lereng 15$30 \%$, batuan permukaaan $15-25 \%$ dan batuan singakapan 15-25\%, dan kedalaman efektif $75-100 \mathrm{~cm}$, curah hujan 2250 - $2500 \mathrm{~mm}$ dan 1000-1250 $\mathrm{mm}$, erosi sedang (S). (Priyono dan Safitri, 1998).

4. Data umur dan pengukuran tinggi/peninggi tanaman akan digunakan untuk menentukan bonita. Untuk menyetarakan dengan sistem klasifikasi lahan, maka bonita juga di kelaskan : bonita 3 menjadi cukup baik untuk jati, 
bonita 3.5 adalah baik untuk jati, bonita 45 adalah sangat baik untuk jati.

5. Data hasil evaluasi lahan dan evaluasi tegakan (bonita) dideskriptifkan secara grafik untuk mengetahui hubungan keduanya.

\section{HASIL DAN PEMBAHASAN}

Hasil

\section{Sebaran Petak Sampel}

Penelitian ini dilakukan di areal Kawasan Hutan Dengan Tujuan Khusus (KHDTK) yang terletak di Kesatuan Pemangkuan Hutan Cepu yang secara administrasi berada di Kabupaten Blora. Petak pengamatan sedapat mungkin mengcover areal KHDTK (Sub-DAS Cemoro Modang). Sebaran petak pengamatan disajikan dalam Gambar 1. berikut :

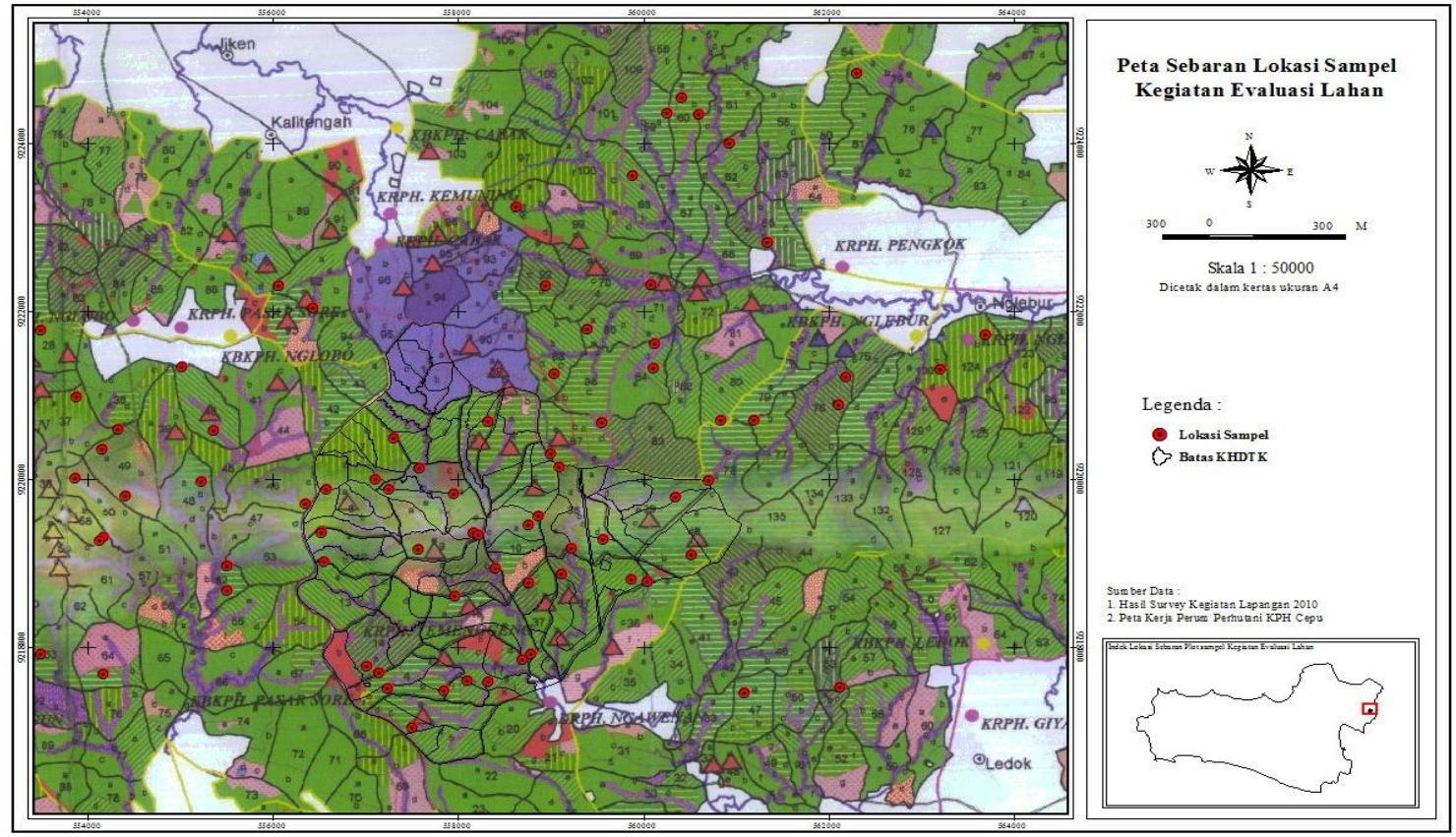

Gambar 1.

Peta Sebaran Petak Pengamatan Evaluasi Lahan

Petak pengamatan diletakkan ditengah - tengah petak-petak tegakan jati disesuaikan dengan kelas umur dan bonitanya. Dalam petak pengamatan yang berukuran 0,1 hektar dilakukan pengukuran diameter dan peningginya serta pencinderaan lahan guna menentukan Kelas Kesesuaian Lahan (KKL). Hasil pengukuran dan pengamatan serta pencinderaan disajikan dalam tabel-tabel dan gambar - gambar di bawah .

\section{Karakteristik Lahan dan Tegakan Jati pada Kawasan Hutan.}

Dari hasil pencinderaan dan data sekunder karakteristik lahan pada kawasan hutan Kesatuan Pemangkuan Hutan (KPH) Cepu diperoleh hasil sebagai berikut :

\section{a. Kondisi Iklim dan Curah Hujan}




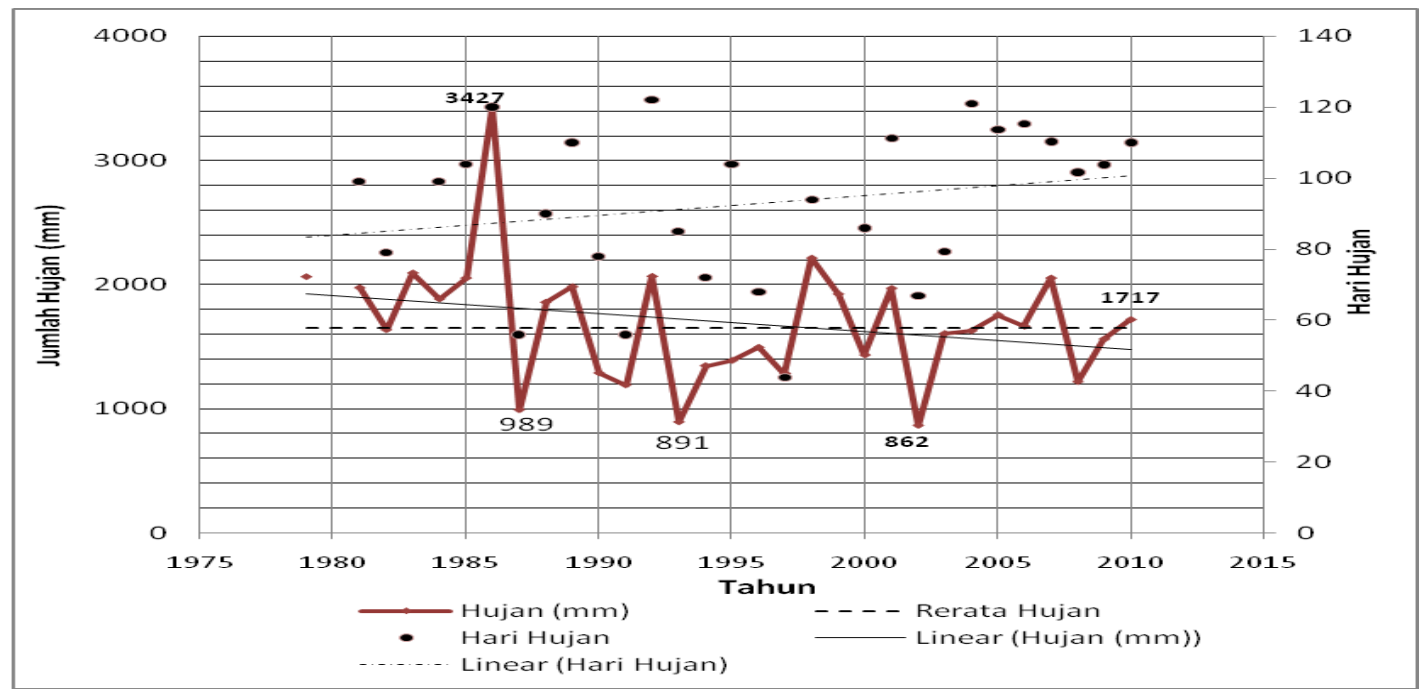

Gambar 2.

Curah Hujan (1979-Agustus 2010, kecuali tahun 1980) di lokasi KHDTK Cemoro Modang DS. Sumber : Olah dan analisis dari data curah hujan yang berasal dari Kecamatan Sambong (1979-

1997) dan beberapa stasiun penakar curah hujan KHDTK Cemoro Modang (1998-2010).

Curah hujan yang terjadi di KHDTK Cemoro Modang rata-rata 1.692 $\mathrm{mm} /$ tahun. Rentang nilai curah hujan terendah yaitu $862 \mathrm{~mm} /$ tahun (tahun 2002) dan terbesar yaitu $3.427 \mathrm{~mm} /$ tahun (tahun 1986). Berdasarkan klasifikasi iklim sistem Schmidt \& Ferguson (1950) dalam Wisnubroto et al (1986); Rafi'i (1995), dari data curah hujan periode pengamatan 1979-2009 iklim di wilayah tersebut termasuk dalam tipe D (sedang) dengan nilai $Q$ sebesar 0,63.

\section{b. Jenis Tanah ( Great-group Tanah)}

Lokasi penelitian didominasi oleh Great-group tanah Ustropepts (53\%), Troporthens (36\%) dan Tropudalfs (11 $\%)$. Great-group tanah yang ada di KHDTK Cemoro-Modang BKPH Pasar Sore, Kejalen, dan Nglebur adalah Tropothents dan Ustropepts.

\section{c. Tegakan Jati}

Keadaan tegakan jati di KPH Cepu secra umum dan areal KHDTK khususnya terdiri dari berbagai Kelas Umur (KU), KU I - KU IX dan juga terdiri dari berbagai Bonita, Bonita 3, 3.5, 4, 4.5 dan
5. Secara umum bonita dominan adalah bonita 3 - 4, bonita 4.5 dan 5 sudah amat jarang diperoleh. Sedangkan Kelas umur secara umum didoninasi oleh KU I - V. Dari 80 petak pengamatan terdapat 77 petak pengamatan dengan bonita $3 ; 3,5 ; 4$; 4,5 dan 5.

\section{Hubungan Bonita dan Kelas Kesesuaian Lahan}

Seperti telah dikemukakan di atas bahwa penilaian kualitas lahan secara bonita hanya dapat dilakukan setelah tanaman mencapai umur tertentu, dan pada lahan kosong atau setelah tebangan mengacu pada hasil risalah RPKH sebelumnya (10 tahun sebelumnya). Sehingga perlu teknik pendugaan lain dalam penilaian kualitas lahan, terutama yang dapat untuk menduga kualitas lahan untuk tanamn jati ketika lahan tersebut dalam keadaan kosong atau dengan kata lain belum tertanami jati. Teknik tersebut adalah dengan Kelas Kesesuaian Lahan/KKL (Land Use Suitibility) dengan metode Inventarisasi Sumber Daya Lahan (ISDL). Hasil dari pendugaan dengan KKL tersebut adalah sebagai berikut : 


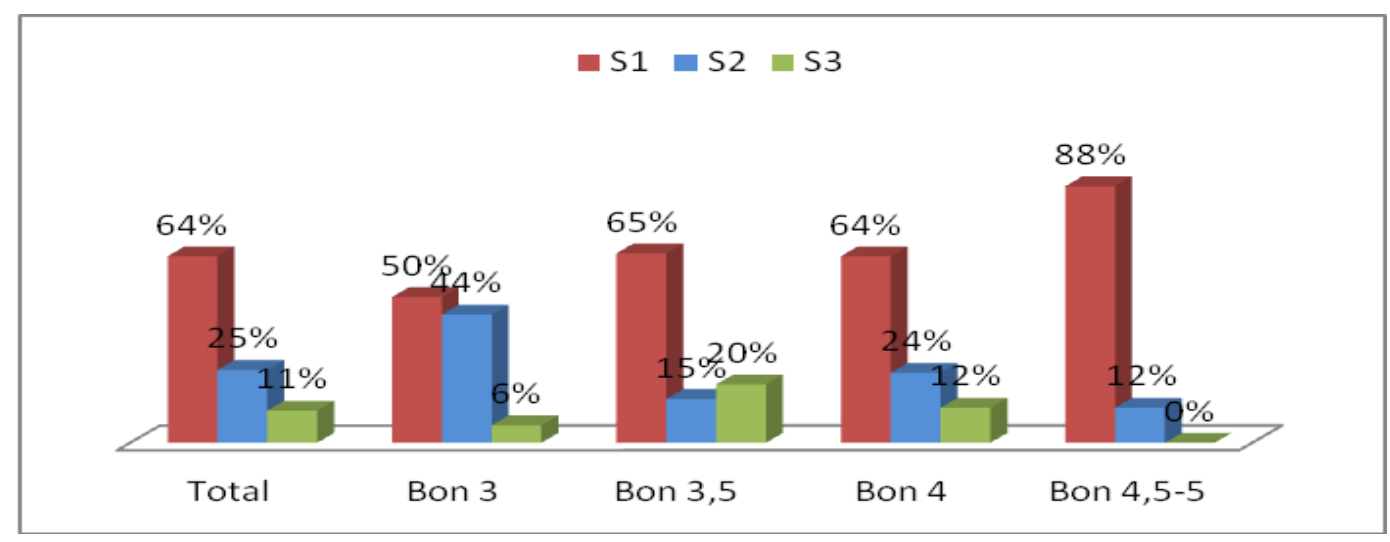

Gambar 3.

Hubungan Bonita dan Kelas Kesesuaian Lahan

Sebagaimana yang telah dikemukakan terdapat 77 petak pengamatan yang terdiri dari bonita 3, 3.5, 4, 4,5 dan 5 dengan pengkelasan bonita 3 menjadi cukup baik untuk jati, bonita 3.5 adalah baik untuk jati, bonita 4-5 adalah sangat baik untuk jati, serta pengkelasan KKL S1 adalah sangat sesuai untuk jati, S2 adalah sesuai untuk jati dan S3 adalah sesuai marjinal untuk jati. Hasil pesetaraan kelas kualitas lahan versi bonita dengan kualitas lahan versi KKL terlihat pada Gambar 3 di atas. Dari gambar tersebut terlihat bahwa secara total dari 77 petak/plot pengamatan, kriteria/kelas $\mathrm{S} 1 \quad$ (sangat sesuai) menempati 64 persen, S2(sesuai) menempati 25 persen dan S3 (sesuai marjinal) menempati 11 persen, sedang apabila kriteria KKL disetarakan dengan kriteria bonita, terlihat bahwa semakin besar/tinggi bonita/kualitas lahan, semakin besar pula persentase kriteria/kelas S1.

\section{Hubungan (Korelasi) Kriteria $\mathbf{S 1}$ (sangat sesuai), S2 (sesuai) dan S3 (sesuai marjinal) dengan Umur dan tinggi tanaman.}

Dari semua yang telah ditampilkan di muka, perlu juga kiranya diketahui korelasi antara kriteria S1, S2 dan S3 dengan parameter tanaman sebagaimana Gambar 4 di bawah :

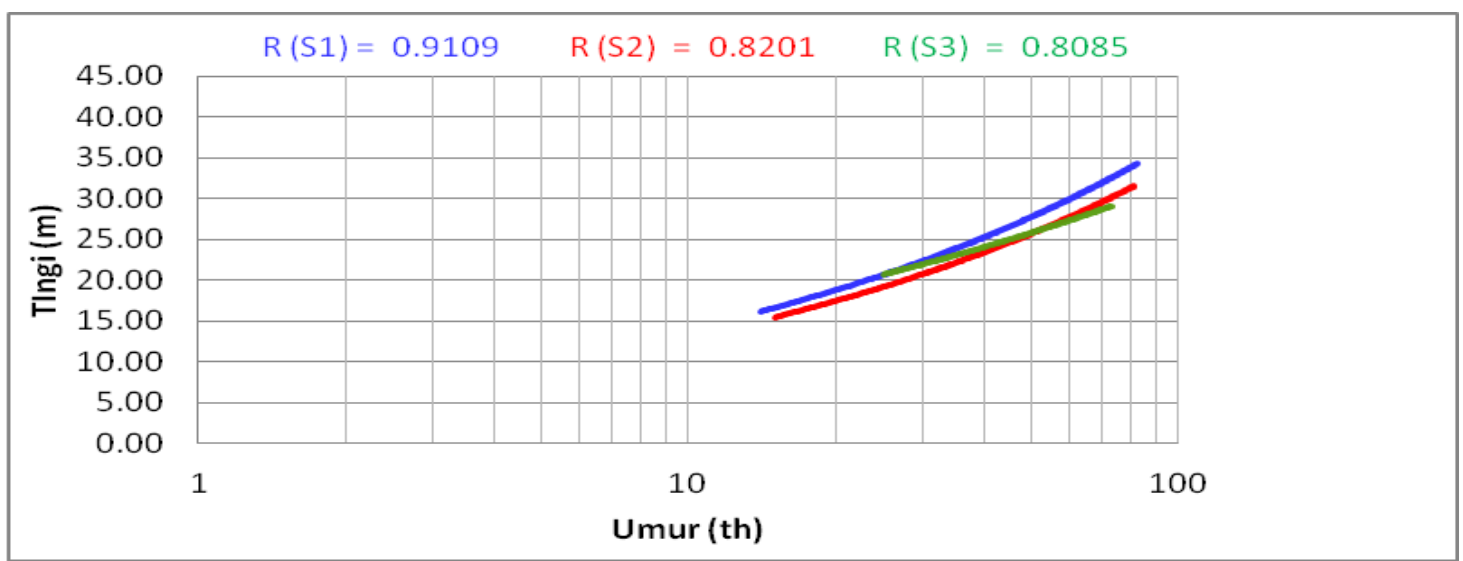

Gambar 4.

Hubungan Umur dan Peninggi Kriteria S1 (sesuai), S2 (sesuai marjinal dan S3 (tidak sesuai) 
Dari nilai $\mathrm{R}$ pada $\mathrm{S} 1, \mathrm{~S} 2$ dan S3 terlihat bahwa masing-masing mempunyai nilai keeratan yang cukup tinggi. Hal ini menunjukkan bahwa penambahan umur pohon juga diikuti dengan penambahan tinggi pohon. Apabila kita perhatikan gambar tersebut terlihat bahwa garis S1 berada di atas garis S2 hampir sejajar (tidak berpotongan), tetapi garis $\mathrm{S} 3$ terlihat memotong garis $\mathrm{S} 1$ maupun $\mathrm{S} 2$.

\section{Pembahasan}

Dari apa yang telah diutarakan di sub bab hasil terlihat terjadi hubungan antara pengkelasan bonita yaitu bonita 4-5 adalah sangat baik untuk jati dengan pengkelasan evaluasi lahan (KKL) yaitu S1 adalah sangat sesuai untuk jati, pengkelasan bonita 3.5 adalah baik untuk jati dengan pengkelasan evaluasi lahan (KKL) yaitu S2 adalah sesuai untuk jati dan pengkelasan bonita 3 menjadi cukup baik untuk jati dengan pengkelasan evaluasi lahan (KKL) yaitu S3 adalah sesuai marjinal untuk jati. Dari Gambar 2. terlihat bahwa pada pesetaraan pengkelasan bonita 4.5-5 dengan pengkelasan evaluasi lahan (KKL) S1 mempunyai hubungan hubungan yang sangat baik yaitu $\mathrm{S} 1$ menduduki 88 persen, hal ini juga ditunjukkan oleh Gambar 3 dimana terlihat bahwa S1 mempunyai hubungan/korelasi yang baik dengan bonita (bonita diwakili peninggi)

Dari hasil penelitian terdahulu, menurut Riyanto dan Pahlana (2012) bahwa telah terjadi perubahan bonita, baik berubah menjadi lebih baik (meningkat) maupun berubah menjadi lebih jelek (menurun), Pada Gambar 2, terlihat bahwa penilaian KKL secara umum pada bonita 3, 3.5, 4, 4.5 dan 5 di petak-petak pengamatan, Kriteria S1 (sesuai) menempati 64 persen, S2 menempati 25 persen dan S3 menempati 11 persen, adanya kelas S2 dan S3 dalam bonitabonita tersebut menunjukkan memang terjadi perubahan kualitas lahan. Masih dalam Gambar 2 memperlihatkan semakin tinggi/besar bonita semakin tinggi persentase kriteria S1 (sesuai), hal ini juga menunjukkan bahwa penilaian kualitas lahan menggunakan KKL untuk jati dapat digunakan.

Dari Gambar 5 terlihat juga bahwa pada pada masing-masing kelas bonita, cukup baik sampai sangat baik terdapat kelas pesetaraan dari sesuai marjinal sampai sangat sesuai. Hal tersebut terjadi karena adanya interaksi antara jenis tanaman dengan lahannya, menurut Mindawati et al (2006) interaksi suaru jenis tanaman dengan kondisi lahan dapat terjadi baik secara positif maupun negatif, tanaman yang tumbuh pada suatu lahan sampai dengan umur tertentu akan mempengaruhi sifat dan kondisi tanahnya. Ini dimungkinkan karena masing-masing jenis tanaman mempunyai sifat fisiologis tersendiri dan masing-masing menghendaki tempat tumbuh yang sesuai dengan sifatnya masing-masing. Selain adanya faktor interaksi antara tanaman dan lahan faktor pengelolaan juga merupakan faktor yang menyebabkan hal di atas terjadi. Hasil penelitian Wahyuningrum dan Priyono (2002) dalam Wahyuningrum dan Basuki (2004) menyebutkan bahwa di beberapa KU tua (> VI) tanaman jati dengan bonita tinggi (>III) pada tegakan hutan jati ternyata menunjukan penurunan kualitas kesuburan tempat tumbuh menjadi sangat rendah, dan dari hasil penentuan kelas kesesuaian terlihat bahwa tingkatannya menjadi sesuai marginal bahkan tidak sesuai untuk tanaman jati.

\section{SIMPULAN}

Evaluasi lahan metode ISDL secara umum dapat dilakukan terutama guna menduga kelas lahan pada waktu lahan tersebut kosong, atau lahan bekas tebangan sekaligus untuk merevisi kelas bonita sebelum tebangan. Dengan bonita 
baru pada tanaman baru, pengelola dapat lebih tepat dalam melakukan pengelolalan petak. Selain itu metode ini juga dapat digunakan pada lahan yang ada tanaman jatinya, maka pada lahan tersebut dapat diprediksi tingkat kualitas suatu lahannya dengan pendekatan Kelas Kesesuaian Lahan (KKL). Pada lahan dengan KKL S1 (sangat sesuai) diperoleh jati sangat baik dengan bonita diatas 4, S2 (sesuai) diperoleh jati baik dengan bonita 3,5 dan S3 (sesuai marjinal) diperoleh jati cukup baik dengan bonita 3 .

Pada lahan di Cepu atau lokasi pengamatan berdasarkan analisis KKL maka diperoleh 64 persen S1 (bonita >4), 25 persen S2 (bonita 3,5) dan 11 persen S3 (bonita 3). Kelas Penggunaan Lahan (KPL) juga dapat dipakai untuk pendekatan bonita yaitu semakin baik KPL (1 dan 4) akan semakin tinggi bonita (>4), sebaliknya semakin buruk KPL (VII dan VIII) maka akan semakin rendah bonita $(<3)$. Hal ini menunjukkan bahwa lahan di Cepu atau lokasi pengamatan masih sangat baik untuk kelas perusahaan jati walau dengan adanya dinamika penurunan dan peningkatan kualitas lahannya. 


\section{DAFTAR PUSTAKA}

Daniel, T.W, John, A.H, Frederick, S.B. $1987 . \quad$ Prinsip-Prinsip

Silvikultur. Gadjah Mada University Press.

Fletcher, J.R; Gibb, R.G. 1990. Land Resources Survey Handbook for Soil Conservation Planning in Indonesia. DSIR Land Resources Scientific Report 11.127.pgs. Published jointly by DSIR Land Resources, New Zealand, Department of Scientific and Industrial Research, and the Directorate General Reforestation and Land Rehabilitation, Ministry of Forestry, Indonesia. Jakarta.

Hardjowigeno, S. 1993. Klasifikasi Tanah dan Pedogenesis. Edisi Pertama. Akademika Pressindo. Jakarta.

Hardwinarto, S. 2009. Sumbangan Hutan Terhadap Hasil Air. Prosiding Workshop Peran Hutan dan Kehutanan dalam Meningkatkan Daya Dukung DAS, 2007. Pusat Penelitian dan Pengembangan Hutan dan Konservasi Alam. Bogor.Kartodihardjo, H. 1997, "Pendekatan Bioregion dalam Pengelolaan Sumber Daya Alam" dalam buku Merangkai Keberagaman, Yayasan KehatiKemitraan-Multistakeholder Forest Program, Jakarta,

Kodoatie, R.J. 009. Peran Hutan dalam Pengendalian Bencana BanjirKekeringan-Tanah Longsor: Identifikasi Masalah dan Teknik Pengendalian. Prosiding Workshop Peran Hutan dan Kehutanan dalam Meningkatkan Daya Dukung DAS, 2007. Pusat Penelitian dan Pengembangan Hutan dan Konservasi Alam. Bogor.
Mahfudz; M.Anis F.; Yuliah; Toni, H.; Prastyono; Henry, S. 2003. Buku Sekilas Tentang Jati (Tectona grandis). Pusat Penelitian dan Pengembangan Bioteknologi dan Pemuliaan Tanaman Hutan. Yogyakarta. Mindawati, N.; A. Syaffari K.; Yetti H. 2006. Pengaruh Penanaman Beberapa Jenis Pohon Hutan Terhadap Kondisi Kesuburan Tanah Andosol. Jurnal Penelitian Hutan Tanaman Vol. 3 No. 3 Juni 2006. Pusat Penelitian dan Pengembangan Hutan Tanaman. Murdyarso, D.; Kurnianto, S. 2009. Peranan Vegetasi Hutan dalam Mengatur Pasokan Air. Prosiding Workshop Peran Hutan dan Kehutanan dalam Meningkatkan Daya Dukung DAS, 2007. Pusat Penelitian dan Pengembangan Hutan dan Konservasi Alam. Bogor.

Nasution, Z. 2005. Evaluasi Lahan Daerah Tangkapan Hujan Danau Toba sebagai dasar perencanaan tata Guna Lahan untuk Pembangunan berkelanjutan. Pidato Pengukuhan Jabatan Guru Besar Tetap Bidang Ilmu Survei Tanah dan Evaluasi Lahan pada Fakultas Pertanian. Kampus USU. Medan

Notohadiprawiro T., 1991. Kemampuan dan Kesesuaian Lahan: Pengertian dan Penetapannya. Lokakarya Neraca Sumberdaya Alam Nasional. DRN Kelompok II-BAKOSURTANAL- $7-9$ Januasri 1991, Bogor.

Notohadiprawiro T., 2006. Kerangka Evaluasi Kemampuan Lahan. Kuliah Pelatihan Inventarisasi dan Evaluasi Sumberdaya Lahan ke-2. Keluarga Mahasiswa 
Tanah, Fakultas Pertanian UGM. Yogyakarta.

Purwanto, E.; Warsito, E. 2001. Deforestasi dan Perubahan Lingkungan Tata Air di Indonesia: Resiko, Implikasi dan Mitos. BIGRAF Publishing. Yogyakarta.

Priyono, C. N.S; Savitri, E. 1998. Metode Penentuan Kesesuaian Lahan Terhadap Jenis Tanaman. Pedoman Teknis. Info DAS No. 3 tahun 1998. Balai Teknologi Pengelolaan Daerah Aliran Sungai. Badan Litbang Kehutanan. Surakarta.

Rachman, S. 2009. Kelembagaan Pengelolaan Daerah Aliran Sungai. Prosiding Workshop Peran Hutan dan Kehutanan dalam Meningkatkan Daya Dukung DAS, 2007. Badan Litbang Kehutanan. Pusat Penelitian dan Pengembangan Hutan dan Konservasi Alam. Bogor.

Ritung S.; Wahyunto; Agus, F.; Hidayat H., 2007. Evaluasi Kesesuaian Lahan: dengan Contoh Peta Arahan Penggunaan Lahan Kabupaten Aceh Barat. Balai Penelitian Tanah dan World Agroforestry Centre.

Riyanto, H.D dan Pahlana, H.U.W. 2012. Kajian Evaluasi Lahan Sistem Bonita Di Kesatuan Pemangkuan Hutan (KPH) Cepu. Jurnal Penelitian Hutan Tanaman Vol. 9 No.1 Maret 2012. Badan Penelitian dan Pengembangan Kehutanan. Pusat Penelitian Dan Pengembangan peningkatan Produktivitas Hutan. Bogor.

Sajjaduzzaman. Md, Abdus Subhan. M, Ralph. M, Nur Muhammad dan Muhammad, T.K. 2005. Site Index For Teak (Tectona grandis Linn.
F.) In Forest Plantation Of Bangladesh. International Journal Of Agriculture and Biology. Vol.7, No.4.

Sakurai K, Yamada Y, Tulaphitak T, Junthotai K, Wacharintarat C, Teejuntuk S, Sahunalu P. 2002. Evaluation Of Site Quality Index For Teak Plantation In Thailand. Symposium of $17^{\text {th }}$ WCSS 14-21 August 2002 Thailand

Simon, H. 2001. Hutan Jati dan Kemakmuran: Problematika dan Strategi Pemecahannya. Cetakan II. BIGRAF Publishing. Yogyakarta.

Siringoringo, H.H., Ign. Purwanto, dan A.Ng. Gintings. 2000. Kriteria Penilaian Tingkat Kesuburan Tanah Hutan. Buletin Penelitian Hutan No. 619/2000. Pusat Penelitian dan Pengembangan Hutan dan Konservasi Alam. Badan Litbang Kehutanan dan Perkebunan. BogorTon Dietz, 1996. Pengakuan Hak atas Sumber Daya Alam: Kontur Geografi Lingkungan Politik. Terjemahan oleh Roem Topatimasang dari Entitlements to Natural Resources: Countours of Political Environmental Geography, International Books, Utrecht, 1996) INSIST Press, Yogyakarta, 1998, hlm. 69-71. 13.

Sudibyakto. 2009. Analisis Tingkat Kekeringan Sebagai Dasar dalam Pengelolaan DAS yang Berhutan di DAS Progo. Prosiding Workshop Peran Hutan dan Kehutanan dalam Meningkatkan Daya Dukung DAS, 2007. Badan Litbang Kehutanan. Pusat Penelitian dan Pengembangan Hutan dan Konservasi Alam. Bogor. 
Sukara E.. 2009. Kerusakan Alam Indonesia Cukup Tinggi. Deputi Bidang Ilmu Pengetahuan Hayati LIPI. http://www.pikiranrakyat.com/index. php $\mathrm{mib}=$ news.detail\&id $=66064$.

Wahyuningrum, N.; Basuki, T.M. Status Kesuburan Tanah di Hutan Tanaman Jati (Tectona grandis, L) Studi Kasus di Bagian Hutan Bnajaran KPH Pati Jawa Tengah. Jurnal Penelitian Hutan dan Konservasi Alam, Vol I, No. 04
Tahun 2004. Badan Penelitian dan Pengembangan Kehutanan. Pusat Penelitaan dan Pengembangan Hutan dan Konservasi Alam. Bogor.

Wirosuprojo S., 2005. Klasifikasi Lahan untuk Perencanaan Penggunaan Lahan di Kabupaten Sleman Daerah Istimewa Yogyakarta. Forum Perencanaan Pembangunan, Edisi Khusus Januari 2005. 